\title{
Subcritical Water for Recovery of Polyphenols from Comfrey Root and Biological Activities of Extracts
}

\author{
Jelena Vladic, ${ }^{1}$ Natasa Nastic, ${ }^{1}$ Tatjana Stanojkovic, ${ }^{2}$ Zeljko Zizak, ${ }^{2}$ \\ Jelena Cakarevic, ${ }^{1}$ Ljiljana Popovic ${ }^{1}$ and Senka Vidovic ${ }^{1, *}$ \\ ${ }^{1}$ Faculty of Technology, University of Novi Sad, Bulevar cara Lazara 1, 21000 Novi Sad, Serbia \\ ${ }^{2}$ Institute of Oncology and Radiology of Serbia, Pasterova 14, 11000 Belgrade, Serbia \\ *Corresponding author: E-mail: senka.curcin@yahoo.com
}

Received: 02-01-2019

\begin{abstract}
In the present study, subcritical water was used for extraction of bioactive compounds of Symphytum officinale root. Temperature $\left(120-200{ }^{\circ} \mathrm{C}\right)$, extraction time (10-30 $\left.\mathrm{min}\right)$ and $\mathrm{HCl}$ concentration in extraction solvent $(0-1.5 \%)$ were investigated as independent variables in order to obtain the optimal conditions for extraction and to maximize the yield of total phenols, flavonoids and antioxidant activity of obtained extracts. The application of optimal conditions $\left(200^{\circ} \mathrm{C}\right.$, $25.6 \mathrm{~min}$ and $0.0075 \%$ ) provided extracts rich in total phenols and flavonoids and high antioxidant activity. Results also demonstrated that subcritical water extraction showed significant advantages for recovery of comfrey root bioactive compounds comparing to maceration and ultrasound-assisted extraction techniques. In addition, subcritical water extracts of S. officinale root are the promising sources of compounds with antioxidant, ACE inhibition, and antiproliferative properties and could potentially be used for production of new pharmacologically-active formulations.
\end{abstract}

Keywords: Symphytum officinale root; Subcritical water extraction; Antioxidant activity; ACE inhibition activity; Antiproliferative activity

\section{Introduction}

Comfrey (Symphytum officinale L.), a member of the genus Boraginacae, is a well-known medicinal plant with large hairy leaves and small purple bellshaped flowers, found predominantly in moist habitats especially beside river. Native in Europe and Asia, the plant has a striking record of medicinal use. The root and leaf have been used externally to treat a wide variety of ailments as well as internally as a decoction for oral and pharyngeal gargle or as a part of dietary supplements. ${ }^{1}$ Comfrey root is used by both traditional and modern herbalists for closing up joint inflammations, musculoskeletal injuries, inflamed breasts and wounds. ${ }^{2-4}$ Its pharmacological properties and clinical efficacy are ascribed mainly to allantoin, rosmarinic acid, mucopolysaccharides, triterpenoids and tannins. ${ }^{5}$ Allantoin is responsible for the stimulation of cell proliferation. It protects tissues and accelerates the healing process, with abundant growth of healthy granulation tissue in slowly healing suppurative wounds. The root of comfrey is also a good source of bioactive compounds including antioxidant polyphe- nols, $\mathrm{A}, \mathrm{B}$ and $\mathrm{C}$ vitamins, steroidal saponins, proteins, inulin, calcium, potassium, copper, sulfur and selenium. ${ }^{6}$

Extraction of bioactive compounds from comfrey root has been investigated in the last few years focusing mainly on conventional solid/liquid extraction. ${ }^{7,8}$ Conventional extraction techniques, however, are quite laborious, time- and solvent-consuming. ${ }^{9}$ They present low efficiency, insufficient selectivity, and use of toxic solvents which further requires additional purification and consequently increases costs. The rising interest in the bioactive compounds and products on basis of herbal materials has resulted in increased demand of the industry to implement contemporary extraction technologies. These technologies aim to provide high yield and standardized quality of products, in a short amount of time. Therefore, a great deal of effort is invested into development of modern extraction technologies, such as ultrasound-assisted extraction (UAE) and subcritical water extraction (SWE), in order to overcome aforementioned disadvantages of classical technologies. Application of innovative technologies and optimization of 
production processes to produce natural products has been in the focus of numerous scientific studies. ${ }^{10-14}$

Ultrasound-assisted extraction has been demonstrated as an advisable tool to recover polyphenols from plant materials, due to its cheapness and maintenance cost. ${ }^{15}$ Report by Wang et al. indicates that UAE reduces processing time, accelerates heat and mass transfer and requires a simple and easy to operate apparatus which helps in easy extraction of thermolabile compounds, without any degradation. ${ }^{16}$ The enhancement of extraction process by ultrasounds is attributed to the cavitation phenomenon and its consequent thermal and mechanical effects which can result in disruption of the cell walls, reduction of the particle size and enhanced mass transfer across cell membrane caused by the collapse of the numerous tiny bubbles.

From the literature review, subcritical water extraction, as a potential alternative to conventional extraction techniques, has been successfully applied to extract target compounds from various matrices mainly due to its safety and compatibility with consecutive applications, environmental concerns and solvent recovery operations. ${ }^{17-21} \mathrm{SWE}$ is based on the use of water at temperatures ranging from boiling point to the critical temperature and pressures high enough to keep the water in a liquid state throughout the extraction process. The change of the dielectric constant of water with temperature results in the possibility of tuning its polarity, for high-selectivity extractions. $^{22}$

The aim of this study was to optimize SWE of polyphenol antioxidants from $S$. officinale root. Response surface methodology and Box-Behnken experimental design were employed to investigate the effect of three process parameters (temperature, time and amount of added acidifier) on the extraction of targeted compounds. Their effect on total phenols and total flavonoids content, as well as on antioxidant activity, was evaluated. Investigated responses were compared in extracts obtained by conventional and novel extraction techniques (UAE, SWE). In addition, ACE inhibition and antiproliferative activities of extracts obtained by using contemporary SWE and UAE, and classical maceration extraction of $S$. officinale root were determined.

\section{Materials and Methods}

\section{1. Chemicals and Reagents}

1,1-Diphenyl-2-picryl-hydrazyl-hydrate was purchased from Sigma-Aldrich (Sternheim, Germany; CAS Number 1898-66-4). Folin-Ciocalteu reagent and gallic acid (CAS Number 149-91-7) were purchased from Merck (Germany). All other reagents used were either analytical or HPLC grade.

\section{2. Plant Sample}

All analysis was performed by using commercial dry S. officinale root supplied by a producer of medicinal plants (Chamomilla, Banatski Karlovac, Vojvodina, Serbia).

\section{3. Preparation of Extracts}

\section{3. 1. Maceration}

Conventional solid-liquid extraction was performed with two different extraction solvents: methanol and ethanol solution $(50 \%, w / w)$. All the extractions were performed by macerating $5.0 \mathrm{~g}$ of dry sample with $50 \mathrm{~mL}$ of extraction solvent at room temperature $\left(25^{\circ} \mathrm{C}\right)$ for $48 \mathrm{~h}$ in a shaker with temperature control (KS 4000i, IKA, Germany) at $150 \mathrm{rpm}$. After extraction, obtained extracts were filtrated through filter paper. Extracts were collected into glass vials and stored at $4{ }^{\circ} \mathrm{C}$ prior analysis.

\section{3. 2. Ultrasound-Assisted Extraction}

Ultrasound-assisted extraction was performed in sonication water bath (EUP540A, Euinstruments, France). The bath consisted of a rectangular container with frequency fixed at $40 \mathrm{kHz}$. The samples of dried powdered $S$. officinale root $(5 \mathrm{~g})$ were placed in a flask $(250 \mathrm{~mL})$ and mixed with $50 \mathrm{~mL}$ of selected solvent (methanol and 50\% ethanol $(\mathrm{w} / \mathrm{w})$ ). The sonication was performed at temperature of $30^{\circ} \mathrm{C}$ and ultrasonic power of $60 \mathrm{~W} / \mathrm{L}$ for $40 \mathrm{~min}$. Flasks with condensers were always positioned in the same distance from the transducer in order to provide constant ultrasonic power. After extraction, extracts were filtered through filter paper under vacuum, collected into glass vials and stored in a dark place at $4{ }^{\circ} \mathrm{C}$ prior analysis.

\section{3. 3. Subcritical Water Extraction}

Subcritical water extraction (SWE) was carried out in a batch-type high-pressure extractor (Parr Instrument Company, USA) using the same experimental process previously described by Zeković et al. ${ }^{23}$ For each run, the extraction cell was filled with $5 \mathrm{~g}$ of dried ground S. officinale root and $50 \mathrm{~mL}$ of double-distilled water. All SFE extractions were performed at 30 bar with different combinations of temperature (120-200 $\left.{ }^{\circ} \mathrm{C}\right)$, extraction time (10-30 $\mathrm{min}$ ) and concentration of $\mathrm{HCl}(0-1.5 \%)$. Obtained extracts were filtrated through filter paper under vacuum, collected into glass vials and stored in a dark place at $4{ }^{\circ} \mathrm{C}$ prior analysis.

\section{4. Analyses of Extracts}

\section{4. 1. Determination of Total Phenols Content and Flavonoids Content}

Vladic et al.: Subcritical Water for Recovery of Polyphenols ... 
The total phenolics (TP) content in obtained $S$. officinale extracts was determined spectrophotometrically using standard Folin-Ciocalteu procedure. ${ }^{24} \mathrm{Ab}$ sorbances of the samples were measured at $750 \mathrm{~nm}$ (6300 Spectrophotometer, Jenway, UK). The results are expressed as g of gallic acid equivalents (GAE) per $100 \mathrm{~g}$ dry weight (DW).

The total flavonoids (TF) content in S. officinale extracts was determined using aluminium chloride colorimetric assay, as reported by Markham. ${ }^{25}$ The absorbance for all tested extracts was measured at 510 $\mathrm{nm}$. The content of total flavonoids was expressed as $\mathrm{g}$ of catechin equivalents (CE) per $100 \mathrm{~g}$ DW.

\section{4 .2. Determination of Antioxidant Activity- DPPH Assay}

Free radical scavenging activities of $S$. officinale subcritical water extracts were evaluated following the procedure previously reported by Espín et al. ${ }^{26}$ Antioxidant activity were expressed as $\mathrm{IC}_{50}$ value, defined as the inhibition concentration of the sample required to inhibit $50 \%$ of radical scavenging capacity $(\mathrm{mg} /$ $\mathrm{mL})$.

\section{4. 3. Analysis of Angiotensin-I-converting Enzyme Inhibition Activity}

Angiotensin-I-converting enzyme (ACE) inhibitory activity was measured following the assay described by Yoshie-Stark et al. ${ }^{27}$ The $\mathrm{IC}_{50}$ value of samples was defined as the inhibition concentration of the sample (in $\mu \mathrm{g} / \mathrm{mL}$ ) required to inhibit $50 \%$ of $\mathrm{ACE}$ activity.

\section{4. 4. Cell Lines - Treatment}

Malignantly cell lines used in this assay (human cervix adenocarcinoma HeLa, breast carcinoma MDA-MB-453, human myelogenous leukemia K562 and human fetal lung fibroblasts MRC-5 cells) were obtained from the American Type Culture Collection (Manassas, VA, USA). All cancer cells were kept in the RPMI-1640 medium supplemented with 10\% heat-inactivated $\left(56{ }^{\circ} \mathrm{C}\right)$ fetal bovine serum (FBS), l-glutamine $(3 \mathrm{mmol} / \mathrm{L})$, streptomycin $(100 \mathrm{mg} / \mathrm{mL})$, penicillin $(100 \mathrm{IU} / \mathrm{mL})$ and $25 \mathrm{mM}$ HEPES, and adjusted to $\mathrm{pH} 7.2$ by bicarbonate solution. Upon reaching confluence, cells were cultured in an atmosphere of $5 \% \mathrm{CO}_{2}$ and $95 \%$ relative humidity at $37^{\circ} \mathrm{C} .200 \mathrm{mg} /$ $\mathrm{ml}$ of Stock solutions of compounds were prepared in dimethylsulfoxide (DMSO), and afterwards diluted in RPMI-1640 medium. HeLa cells (2000 cells per well), MDA-MB-453 cells (3000 cells per well), and MRC-5 cells (5000 cells per well) were distributed in sterile 96-well microtiter plates, and were cultured for $20 \mathrm{~h}$.
Thereafter, the cells were treated with investigated extracts of various concentrations. The concentrations tested were in the range of 0.0625 to $2 \mathrm{mg} / \mathrm{mL}$. In control wells, only nutrient medium was added to the cells. The investigated extracts were added to a suspension of K562 cells (5000 cells per well) $2 \mathrm{~h}$ after cell seeding, in the same final concentrations. The cultures were incubated for $72 \mathrm{~h}$ at $37^{\circ} \mathrm{C}$ in a humidified incubator with $5 \% \mathrm{CO}_{2}$.

\section{Determination of cell survival (MTT test)}

The influence of S. officinale extracts on the viability of malignantly transformed cell lines was determined by MTT (microculture tetrazolium test) following the procedure described by Mosmann ${ }^{28}$ with slight modification by Ohno and Abe ${ }^{29} 72$ hours after the investigated extract was added. Briefly, $20 \mu \mathrm{L}$ of MTT solution $(5 \mathrm{mg} / \mathrm{mL}$ in phosphate buffered saline (PBS)) was added to each well and plates were incubated for a further $4 \mathrm{~h}$ at $37^{\circ} \mathrm{C}$ in $5 \% \mathrm{CO}_{2}$ humidified atmosphere. After incubation, the MTT formazan crystals were dissolved by adding $100 \mu \mathrm{l}$ of $10 \%$ SDS to each well. The number of viable cells was measured by detecting absorbance in an ELISA microplate reader at a wavelength of $570 \mathrm{~nm} 24 \mathrm{~h}$ later. The cell survival (\%) was calculated as absorbance of treated cells divided with absorbance of control cells and multiplied with 100. Cell growth inhibitions were expressed as $\mathrm{IC}_{50}$ values, defined as the concentrations of sample required to inhibit $50 \%$ of cell survival. All experiments were done in triplicate.

\section{5. Design of Experiments and Statistical Analysis}

Response surface methodology was employed to study the effect of independent variables temperature $\left(\mathrm{X} 1,120-200{ }^{\circ} \mathrm{C}\right)$, extraction time (X2, 10-30 min) and $\mathrm{HCl}$ concentration $(\mathrm{X} 3,0-1.5 \%)$ on the total phenols content, total flavonoids content and antioxidant activity parameters as responses. The Box-Behnken experimental design (BBD) was selected to propose the model for the investigated responses. The experimental design consisted of fifteen trials in random order, including three replicates at the central point. Table 1 shows the three independent variables encoded to three levels $(-1,0$ and 1$)$.

Table 1. Box-Behnken experimental design with natural and coded levels of SWE parameters

\begin{tabular}{lccc}
\hline Independent variable & \multicolumn{3}{c}{ Factor levels } \\
& $(\mathbf{- 1 )}$ & $\mathbf{( 0 )}$ & $\mathbf{( 1 )}$ \\
\hline Temperature $\left({ }^{\circ} \mathrm{C}\right)$ & 120 & 160 & 200 \\
Extraction time $(\mathrm{min})$ & 10 & 20 & 30 \\
Concentration $\mathrm{HCl}(\%)$ & 0 & 0.75 & 1.5 \\
\hline
\end{tabular}


A second-order polynomial model (Eq. (3)) was fitted to results in order to correlate the relationship of each factor to the response: ${ }^{30}$

$$
\mathrm{Y}=\beta_{0}+\sum \beta_{\mathrm{i}} \mathrm{X}_{\mathrm{i}}+\sum \mathrm{b}_{\mathrm{ii}} \mathrm{X}_{\mathrm{ii}}^{2}+\sum \mathrm{b}_{\mathrm{ij}} \mathrm{X}_{\mathrm{i}} \mathrm{X}_{\mathrm{j}}
$$

where $\mathrm{Y}$ represents the response variable, $\mathrm{Xi}$, Xii and $\mathrm{XiXj}$ represent the linear, quadratic, and interactive terms of the coded independent variables, respectively, and $\beta 0, \beta \mathrm{i}, \beta \mathrm{ii}$, and $\beta \mathrm{ij}$ are the regression coefficients for intercept, linearity, quadratic, and interaction intercept terms, respectively. Analysis of variance (ANOVA) was carried out to identify the adequacy of the developed model with the significance levels of 0.05 (significant) and 0.10 (moderately significant). The coefficient of multiple determination $\left(\mathrm{R}^{2}\right)$, coefficient of variance $(\mathrm{CV})$ and p-values for the model and lack of fit coefficient were obtained from analysis of variance. The statistical software Design-Expert v.7 Trial (Stat-Ease, Minneapolis, Minnesota, USA) was employed for the all computation and graphics in this study.

\section{Results and Discussion}

\section{1. Statistical Analysis and Model Fitting}

In this study, a Box-Behnken design was carried out to optimize the procedure for the extraction of phenolic compounds using SWE. The investigated response values (TP and TF content, and antioxidant activity) for different combination of SWE parameters (extraction temperature, extraction time and $\mathrm{HCl}$ concentration) are presented in Table 2.
The experimental results of SWE were fitted to a second-order polynomial model (Eq. (3)). Multiple regression coefficients for linear, interaction and quadratic terms were achieved using method of least square (MLS) (Table 3).

Table 3. Estimated coefficients of second-order polynomial models for investigated responses

\begin{tabular}{lccr}
\hline $\begin{array}{l}\text { Regression } \\
\text { coefficient }\end{array}$ & TP & $\begin{array}{c}\text { Response } \\
\text { TF }\end{array}$ & IC $_{50}$ \\
\hline $\begin{array}{l}\text { Intercept } \\
\beta_{0}\end{array}$ & +3.99696 & +1.43103 & +0.016078 \\
Linear & & & \\
$\beta_{1}$ & $+2.02431^{*}$ & $+0.60021^{*}$ & $-9.04385 \times 10^{-3^{*}}$ \\
$\beta_{2}$ & +0.44419 & +0.12192 & $-4.92939 \times 10^{-4}$ \\
$\beta_{3}$ & -0.13947 & $-0.39902^{*}$ & $+2.44993 \times 10^{-3}$ \\
Interaction & & & \\
$\beta_{12}$ & +0.082186 & +0.080163 & $+4.22203 \times 10^{-4}$ \\
$\beta_{13}$ & -0.63150 & $-0.41380^{*}$ & $-9.44828 \times 10^{-5}$ \\
$\beta_{23}$ & -0.60841 & -0.10725 & $+5.20550 \times 10^{-4}$ \\
Quadratic & & & \\
$\beta_{11}$ & +0.21706 & +0.14668 & $+1.96614 \times 10^{-3}$ \\
$\beta_{22}$ & +0.22050 & $+0.27633^{*}$ & $+3.11321 \times 10^{-3}$ \\
$\beta_{33}$ & -0.45832 & +0.15653 & $-1.53053 \times 10^{-3}$ \\
$\mathrm{R}^{2 \mathrm{a}}$ & 0.9654 & 0.9738 & \\
\hline \multirow{2}{*}{ Significant at 0.05 level } & & 0.9569 \\
\multicolumn{2}{c}{ a Coefficient of multiple determination } &
\end{tabular}

Analysis of variance (ANOVA) was employed to check adequacy of the applied models and the results are summarized in Table 4. Statistical analysis suggested that the experimental values correlate well with the models. Good model fitness has been confirmed by highly significant $p$-values $(p<0.05)$ for all models.

Table 2. Natural values of independent variables for Box-Behnken design and experimentally observed responses (TP, TF, $\mathrm{IC}_{50}$ ) in obtained extracts

\begin{tabular}{|c|c|c|c|c|c|c|}
\hline \multirow{2}{*}{$\begin{array}{l}\text { Run } \\
\text { order }\end{array}$} & \multicolumn{3}{|c|}{ Independent variables } & \multicolumn{3}{|c|}{ Investigated responses } \\
\hline & $\mathbf{T}\left({ }^{\circ} \mathbf{C}\right)$ & $t(\min )$ & c $\mathrm{HCl}(\%)$ & $\begin{array}{c}\text { TP } \\
(\mathrm{g} \mathrm{GAE} / 100 \mathrm{~g})\end{array}$ & $\begin{array}{c}\text { TF } \\
(\mathrm{g} \mathrm{CE} / 100 \mathrm{~g})\end{array}$ & $\begin{array}{c}\mathrm{IC}_{50} \\
(\mathrm{mg} / \mathrm{mL})\end{array}$ \\
\hline 1 & 160 & 10 & 1.5 & 3.24 & 1.33 & 0.0191 \\
\hline 2 & 120 & 20 & 0 & 1.11 & 0.97 & 0.0203 \\
\hline 3 & 120 & 10 & 0.75 & 2.16 & 1.23 & 0.0329 \\
\hline 4 & 160 & 20 & 0.75 & 3.90 & 1.39 & 0.0160 \\
\hline 5 & 160 & 20 & 0.75 & 3.91 & 1.49 & 0.0175 \\
\hline 6 & 200 & 10 & 0.75 & 6.34 & 2.23 & 0.0105 \\
\hline 7 & 200 & 30 & 0.75 & 6.87 & 2.64 & 0.0103 \\
\hline 8 & 160 & 20 & 0.75 & 4.19 & 1.41 & 0.0147 \\
\hline 9 & 200 & 20 & 0 & 6.13 & 3.04 & 0.0059 \\
\hline 10 & 200 & 20 & 1.5 & 5.14 & 1.67 & 0.0125 \\
\hline 11 & 160 & 30 & 0 & 5.49 & 2.62 & 0.0152 \\
\hline 12 & 160 & 10 & 0 & 2.87 & 2.17 & 0.0171 \\
\hline 13 & 120 & 20 & 1.5 & 2.65 & 1.26 & 0.0273 \\
\hline 14 & 160 & 30 & 1.5 & 3.44 & 1.34 & 0.0192 \\
\hline 15 & 120 & 30 & 0.75 & 2.37 & 1.32 & 0.0310 \\
\hline
\end{tabular}

Vladic et al.: Subcritical Water for Recovery of Polyphenols ... 
For all three investigated responses, mathematical models proved to be statistically acceptable due to insignificant lack of fit $(p>0.05)$. Validity of the models has been also confirmed by significant regression $(p<$ $0.05)$. Furthermore, considering particularly high determination coefficients $\left(R^{2}>0.90\right)$ for the TP content,
TF content, and $\mathrm{IC}_{50}$ values $(0.965,0.974$ and 0.957 , respectively), applied second-order polynomial model is well adjusted to the experimental results. Considering the obtained values, these data were used for creation of response surface 3D plots for each experimental model.

Table 4. Analysis of variance (ANOVA) of the fitted second-order polynomial model for TP content, $\mathrm{TF}$ content and $\mathrm{IC}_{50}$ value

\begin{tabular}{|c|c|c|c|c|c|}
\hline & Sum of squares & DF & Mean Square & $F$-value & $p$-value \\
\hline \multicolumn{6}{|l|}{ TP content } \\
\hline Model & 38.84 & 9 & 4.32 & 15.51 & 0.0038 \\
\hline $\mathbf{T}$ & 32.78 & 1 & 32.78 & 117.84 & 0.0001 \\
\hline $\mathbf{t}$ & 1.58 & 1 & 1.58 & 5.67 & 0.0630 \\
\hline c & 0.16 & 1 & 0.16 & 0.56 & 0.4882 \\
\hline $\mathbf{T} \times t$ & 0.027 & 1 & 0.027 & 0.097 & 0.7679 \\
\hline $\mathbf{T} \times \mathbf{c}$ & 1.60 & 1 & 1.60 & 5.73 & 0.0620 \\
\hline$t \times c$ & 1.48 & 1 & 1.48 & 5.32 & 0.0692 \\
\hline $\mathbf{T}^{2}$ & 0.17 & 1 & 0.17 & 0.63 & 0.4649 \\
\hline $\mathbf{t}^{2}$ & 0.18 & 1 & 0.18 & 0.65 & 0.4583 \\
\hline$c^{2}$ & 0.78 & 1 & 0.78 & 2.79 & 0.1558 \\
\hline Residual & 1.39 & 5 & 0.28 & & \\
\hline Lack of Fit & 1.34 & 3 & 0.45 & 16.28 & 0.0584 \\
\hline Pure Error & 0.055 & 2 & 0.027 & & \\
\hline Cor Total & 40.23 & 14 & & & \\
\hline \multicolumn{6}{|l|}{ TF content } \\
\hline Model & 5.43 & 9 & 0.60 & 20.65 & 0.0019 \\
\hline $\mathbf{T}$ & 2.88 & 1 & 2.88 & 98.63 & 0.002 \\
\hline $\mathbf{t}$ & 0.12 & 1 & 0.12 & 4.07 & 0.0997 \\
\hline c & 1.27 & 1 & 1.27 & 43.59 & 0.0012 \\
\hline $\mathbf{T} \times t$ & 0.026 & 1 & 0.026 & 0.88 & 0.3914 \\
\hline $\mathrm{T} \times \mathrm{c}$ & 0.68 & 1 & 0.68 & 23.44 & 0.0047 \\
\hline tx c & 0.046 & 1 & 0.046 & 1.57 & 0.2650 \\
\hline $\mathbf{T}^{2}$ & 0.079 & 1 & 0.079 & 2.72 & 0.1601 \\
\hline $\mathbf{t}^{2}$ & 0.28 & 1 & 0.28 & 9.65 & 0.0267 \\
\hline$c^{2}$ & 0.090 & 1 & 0.090 & 3.10 & 0.1388 \\
\hline Residual & 0.15 & 5 & 0.029 & & \\
\hline Lack of Fit & 0.14 & 3 & 0.047 & 15.83 & 0.0600 \\
\hline Pure Error & $5.905 \times 10^{-3}$ & 2 & $2.952 \times 10^{-3}$ & & \\
\hline Cor Total & 5.58 & 14 & & & \\
\hline \multicolumn{6}{|l|}{$\mathrm{IC}_{50}$ value } \\
\hline Model & $7.664 \times 10^{-4}$ & 9 & $8.515 \times 10^{-5}$ & 512.30 & 0.0065 \\
\hline $\mathbf{T}$ & $6.543 \times 10^{-4}$ & 1 & $6.543 \times 10^{-4}$ & 494.49 & 0.0002 \\
\hline $\mathbf{t}$ & $1.944 \times 10^{-6}$ & 1 & $1.944 \times 10^{-6}$ & $\begin{array}{l}6 \\
6.28\end{array}$ & 0.6189 \\
\hline c & $4.802 \times 10^{-5}$ & 1 & $4.802 \times 10^{-5}$ & $5 \quad 6.93$ & 0.0463 \\
\hline $\mathbf{T} \times \mathbf{t}$ & $7.130 \times 10^{-7}$ & 1 & $7.130 \times 10^{-7}$ & $\begin{array}{l}7 \\
7\end{array}$ & 0.7613 \\
\hline $\mathrm{T} \times \mathrm{c}$ & $3.571 \times 10^{-8}$ & 1 & $3.571 \times 10^{-8}$ & $\begin{array}{l}8 \\
8.157 \times 10^{-3}\end{array}$ & ${ }^{-3} 0.9455$ \\
\hline$t \times c$ & $1.084 \times 10^{-6}$ & 1 & $1.084 \times 10^{-6}$ & $\begin{array}{l}6 \\
6\end{array}$ & 0.7087 \\
\hline $\mathrm{T}^{2}$ & $1.427 \times 10^{-5}$ & 1 & $1.427 \times 10^{-5}$ & $5 \quad 2.06$ & 0.2106 \\
\hline $\mathbf{t}^{2}$ & $3.579 \times 10^{-5}$ & 1 & $3.579 \times 10^{-5}$ & $5 \quad 5.17$ & 0.0721 \\
\hline$c^{2}$ & $8.649 \times 10^{-6}$ & 1 & $8.649 \times 10^{-6}$ & $\begin{array}{ll}6 & 1.25\end{array}$ & 0.3145 \\
\hline Residual & $3.462 \times 10^{-5}$ & 5 & $6.925 \times 10^{-6}$ & & \\
\hline Lack of Fit & $3.053 \times 10^{-5}$ & 3 & $1.018 \times 10^{-5}$ & $5 \quad 4.97$ & 0.1721 \\
\hline Pure Error & $4.097 \times 10^{-5}$ & 2 & $2.049 \times 10^{-6}$ & & \\
\hline Cor Total & $8.010 \times 10^{-4}$ & 14 & & & \\
\hline
\end{tabular}

Vladic et al.: Subcritical Water for Recovery of Polyphenols ... 


\section{2. Influence of Independent Variables on the Investigated Dependent Variables}

Total phenolic content observed in S. officinale root extracts obtained under different SWE conditions ranged from 1.11 to $6.87 \mathrm{~g} \mathrm{GAE} / 100 \mathrm{~g}$ DW. The highest TP content was observed at temperature of $200{ }^{\circ} \mathrm{C}$, extraction time of $30 \mathrm{~min}$ and $\mathrm{HCl}$ concentration of $0.75 \%$, while the lowest TP content was obtained at temperature of $120^{\circ} \mathrm{C}$ and extraction time of 20 min without added acid modifier (Table 2). All SWE extracts obtained at $200{ }^{\circ} \mathrm{C}$ had significantly higher TP content comparing to extracts obtained at 120 and $160^{\circ} \mathrm{C}$. According to ANOVA analysis, the linear temperature terms had an important influence $(p<0.05)$, while other effects were not statistically important (Table 4). Based on the sum of squares, the importance of the independent variables on TP content was insignificant, as well as their interactions. Determination of regression coefficients using the least squares method provided the predictive model equation for TP extraction depicted in the Table 5. ed highly significant influence on TF content, while linear influence of extraction time was insignificant. Extraction temperature expressed the most significant positive effect on TF meaning that TF will significantly increase with increasing the temperature, which is in accordance with experimental results obtained for $\mathrm{TP}$ content. Linear term of $\mathrm{HCl}$ concentration exhibited negative influence on TF content, which imply that comfrey root flavonoids were better extracted if reduced acidifier concentration in extraction solvent were applied. Also, the interaction term between temperature and $\mathrm{HCl}$ concentration interaction affected TP content negatively. This means that elevated temperature and increased $\mathrm{HCl}$ concentration caused reduction in TF content, probably due to thermal degradation of flavonoid compounds on these severe extraction conditions. Quadratic term of extraction time exhibited significant positive influence on TF content. This suggested that an increase of extraction time increased the TF content of $S$. officinale extract. The response surface plots describing influences of SWE parameters on TF content of $S$. officinale root ex-

Table 5. Model equations which are able to predict response values within investigated experimental domain

\begin{tabular}{ll}
\hline Response & Second-order polynomial equation \\
\hline TP content & $\mathrm{TP}=3.9969+2.0243 \mathrm{X}_{1}$ \\
TF content & $\mathrm{TF}=1.43103+0.60021 \mathrm{X}_{1}-0.39902 \mathrm{X}_{3}-0.41380 \mathrm{X}_{1} \mathrm{X}_{3}+0.27633 \mathrm{X}_{2}^{2}$ \\
IC $_{50}$ value & $\mathrm{IC}_{50}=0.0161-9.04385 \times 10^{-3} \mathrm{X}_{1}+2.44993 \times 10^{-3} \mathrm{X}_{3}$ \\
\hline
\end{tabular}

The combined effect of the extraction parameters on the TP content of $S$. officinale root extracts obtained by SWE is presented in Figure 1a. The TP content increased linearly with temperature, while the extraction time did not influence this investigated response. The $\mathrm{HCl}$ concentration effect on phenols extraction of obtained extracts was rather insignificant. Similar findings for SWE of phenolic compounds were previously reported for other plant species. ${ }^{23,31}$ In subcritical water extraction, temperature is one of the most prominent operational parameter that affect the efficiency and selectivity of the process. Water at high temperatures breaks bonds between phenolics and cell wall releasing them more efficiently. ${ }^{32}$ Elevated temperatures enhance also the diffusion rate and desorption kinetics, resulting in a decrease in its viscosity and surface tension. ${ }^{22} \mathrm{~A}$ decrease in solvent surface tension allows better pore filling, thus permitting analytes to be better solubilised.

Concerning the total flavonoids content, predictive second-order polynomial model equation, which is able to describe influence of SWE parameters on investigated response, is presented on Table 5. The linear terms of temperature and $\mathrm{HCl}$ concentration exhibit- tracts are shown in Figure 1b. TF content of extracts ranged from 0.97 to $3.04 \mathrm{~g} \mathrm{CE} / 100 \mathrm{~g}$ DW. The highest $\mathrm{TF}$ value was measured in the samples obtained at a temperature of $200{ }^{\circ} \mathrm{C}$ and extraction time of $20 \mathrm{~min}$, but with the absence of $\mathrm{HCl}$. Extracts obtained at 120 ${ }^{\circ} \mathrm{C}$, for $20 \mathrm{~min}$, without using acid modifier, exhibited the lowest TF content.

Experimentally obtained values of antioxidant activity observed in S. officinale root extracts obtained by SWE are presented in Tables 2 and 4. The antioxidant activity of comfrey root extracts is not affected by extraction time, while the temperature and $\mathrm{HCl}$ concentration had a significant influence on this property, as it was the case with TF content. Linear terms of temperature displayed highly significant negative influence on investigated response $\left(\mathrm{IC}_{50}\right.$ value). On the other hand, $\mathrm{HCl}$ concentration exhibited significant positive influence on $\mathrm{IC}_{50}$ value, which means that pure, or slightly acidified water should be used as extraction solvent. The final equation which could predict the behaviour of the investigated response is shown in Table 5. Depending on the extraction parameters antioxidant activity of extracts varied from 0.0059 to $0.0329 \mathrm{mg} /$

Vladic et al.: Subcritical Water for Recovery of Polyphenols ... 
(a)
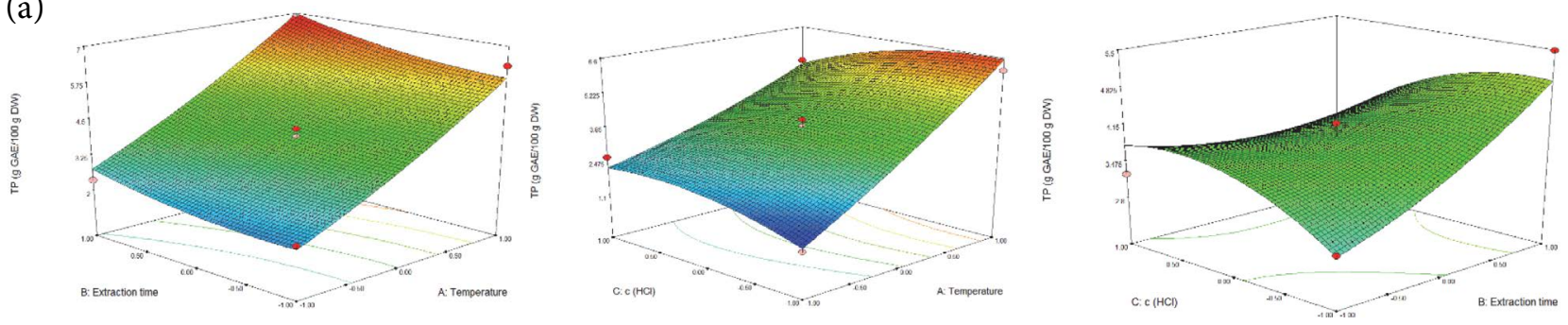

(b)
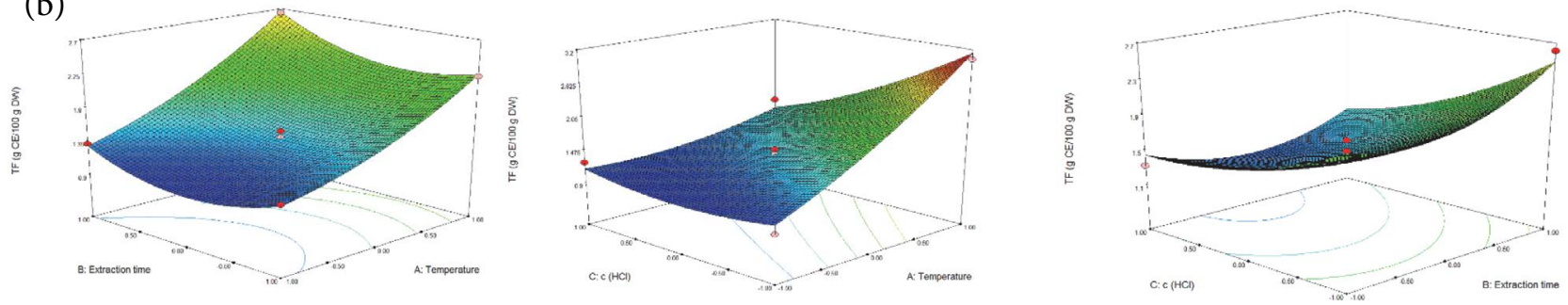

(c)
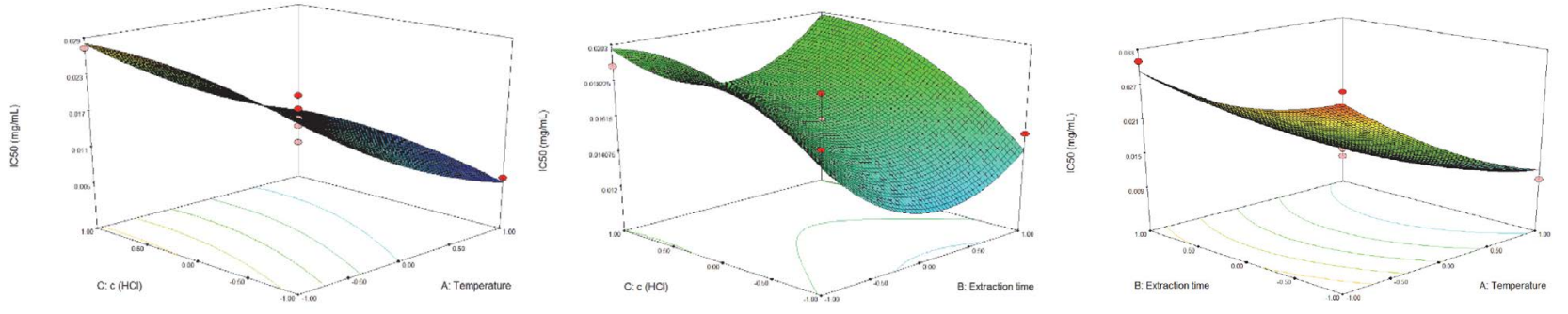

Figure 1. Response surface of TP content (a), TF content (b) and $\mathrm{IC}_{50}$ value (c) as simultaneous function of temperature, extraction time and $\mathrm{HCl}$ concentration

$\mathrm{mL}$. The highest antioxidant activity was measured in the extracts obtained at a temperature of $200{ }^{\circ} \mathrm{C}$ and extraction time of 20 min without using $\mathrm{HCl}$ modifier. On the other hand, extracts obtained at $120^{\circ} \mathrm{C}$ for $10 \mathrm{~min}$ using $0.75 \% \mathrm{HCl}$ as extraction solvent, showed the lowest antioxidant activity. Antioxidant activity significantly increased with the increase in extraction temperatures from 120 to $200{ }^{\circ} \mathrm{C}$ being in accordance with the content of polyphenols and flavonoids. These findings were in agreement with previously published studies on using SWE for the isolation of natural antioxidants where antioxidant activity increased with temperature up to $200^{\circ} \mathrm{C}$ in SWE of deodorized thyme. ${ }^{33} \mathrm{He}$ et al. ${ }^{34}$ also examined the effects of temperature on the antioxidant activity of pomegranate seed residues extracts. The highest antioxidant activities were seen when extraction was performed at temperature between 180 and $240^{\circ} \mathrm{C}$. The high antioxidant activity of extracts acquired at such relatively high temperature may have been related to the formation of new bioactive compounds during the extraction process via Maillard reactions. ${ }^{33}$ Visual representation of extraction parameters influence on antioxidant activity in comfrey root extracts is given in Figure 1c. Moreover, moderate correlation between $\mathrm{IC}_{50}$, TP and TF can be noticed, proving that polyphenols were the most important compounds responsible for antioxidant activity of S. officinale root.

Regarding all these aspects, the efficiency of extraction of phenolic compounds and antioxidative activity of SWE extracts depend on temperature directly. Extraction time had a negligible effect on all three investigated variables, while $\mathrm{HCl}$ concentration affected TF content and antioxidant activity. Other authors that dealt with subcritical water extraction came to similar conclusion. ${ }^{17,31.35}$ However, in order to gain complete information about extraction parameters effect on investigated responses during SWE of S. officinale root, further studies including chemical characterization of the extracts and the identification of responsible bioactive compounds are required.

\section{3. Optimization of Process Parameters}

Optimization of SWE process was the primary subject of this work, which allowed setting process parameters that maximized the value of all investigated 
responses. Optimized extraction conditions for maximized yields of $\mathrm{TP}, \mathrm{TF}$, and minimized $\mathrm{IC}_{50}$ value, i.e. maximized antioxidant activity are presented in Table 6 . By applying the response surface methodology and the multiple response optimization in the experimental domain investigated, the optimal process parameters of all three responses simultaneously of S. officinale root were determined to be as follows: temperature of $200{ }^{\circ} \mathrm{C}$, extraction time of $25.6 \mathrm{~min}$ and $0.0075 \%$ $\mathrm{HCl}$ concentration in extraction solvent. Predicted values of investigated responses on these conditions were $7.26 \mathrm{~g} \mathrm{GAE} / 100 \mathrm{~g}$ DW, $3.40 \mathrm{~g} \mathrm{CE} / 100 \mathrm{~g}$ DW and $0.0058 \mu \mathrm{g} / \mathrm{mL}$, for TP, TF and $\mathrm{IC}_{50}$, respectively. Determination of optimal conditions and predicted values was based on desirability function, $D=1$. The results showed that there was no significant difference observed between the predicted values and experimental ones, indicating that the model was adequate for reflecting the expected optimization. In addition, the extract obtained under optimal conditions was used for further analysis.

Table 6. Optimized extraction conditions for maximized yields of $\mathrm{TP}$ and $\mathrm{TF}$ and minimized $\mathrm{IC}_{50}$ value

\begin{tabular}{llccc}
\hline & & \multicolumn{3}{c}{ Investigated variable } \\
& & TP & TF & IC $_{\mathbf{5 0}}$ \\
\hline Optimal & Temperature & 200 & 197.60 & 200 \\
extraction & Extraction time & 29.2 & 29.9 & 21.1 \\
condition & $\mathrm{c}(\mathrm{HCl})$ & 0.3375 & 0.075 & 0.0225 \\
\hline & Optimal value & 7.50 & 3.52 & 0.00527 \\
\hline
\end{tabular}

\section{4. Comparison of Extraction Techniques}

Currently, literature data concerning S. officinale root extracts is very limited. In the present study, subcritical water extracts of $S$. officinale root obtained under optimal conditions $\left(200^{\circ} \mathrm{C}, 25.6 \mathrm{~min}\right.$, and $0.0075 \%$ $\mathrm{HCl}$ ) were compared to those obtained by conventional extraction and ultrasound-assisted extraction, where

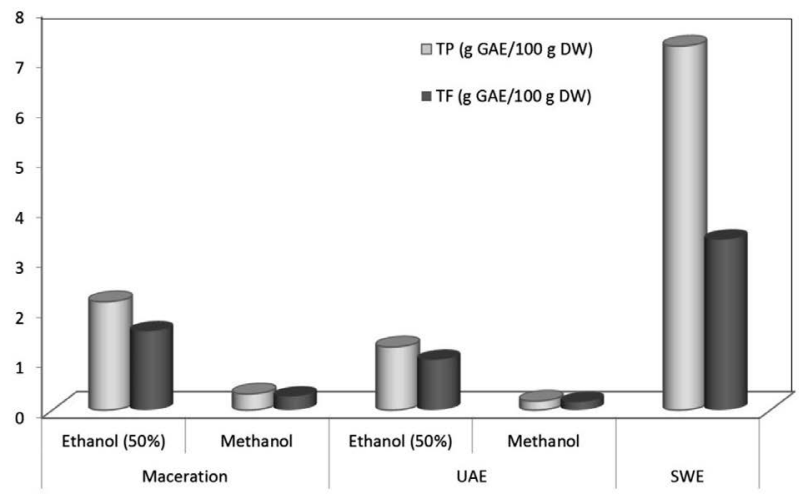

Figure 2. Total phenolic, total flavonoid contents of comfrey root extracts obtained by different extraction techniques ethanol (50\%) and methanol were used as extraction solvents (Figure 2; Supplementary data, Table 1).

SWE was found to be much more efficient for extraction of TP and TF from S. officinale root in comparison to maceration and UAE. Lower TP and TF contents were observed by Alkan et al. ${ }^{36}$ in methanolic and aqueous extracts of comfrey root obtained by Soxhlet extraction and decoction method. Furthermore, antioxidant activity obtained by SWE was significantly higher comparing to that obtained by maceration and UAE with ethanol and methanol. Moderately high antioxidant activity of $S$. officinale ethanolic extract $(0.0397 \mathrm{mg} / \mathrm{mL})$ was reported by Alkan et al. ${ }^{36}$ According to the results from Figure 2, addition of methanol showed the lowest recovering capacity for bioactive compounds from comfrey root. Addition of ethanol to the water improved her capabilities to extract these bioactive compounds. But, by application of increased pressure and temperature, and transformation of water into the subcritical state, these capabilities were much more improved. These observations are related to dielectric constant of extraction solvent. In subcritical conditions, as the temperature of water is increased, the polarity of water decreases. That allows dissolving compounds of intermediate or low polarity. The dielectric constant of water decreases with the temperature (e.g., from $\varepsilon=80$ at ambient temperature to $\varepsilon=27$ at $250^{\circ} \mathrm{C}$ ) and becomes close to that of methanol $\left(\varepsilon=33.6\right.$ at $\left.25^{\circ} \mathrm{C}\right)$ and etha$\operatorname{nol}\left(\varepsilon=24.5\right.$ at $\left.25^{\circ} \mathrm{C}\right) .^{37}$

In addition, SWE process only needed $25.6 \mathrm{~min}$ to reach significantly higher values of investigated responses, while extraction time for maceration was 48 $\mathrm{h}$ and for UAE $40 \mathrm{~min}$. This might be due to the dissolving properties of subcritical water, thus providing a much faster mass transfer. Given the advantages of used solvent, including its safety, selectivity and low cost, functionality, good yields of target compounds and reduced energy consumption, make this technique favorable for potential industrial applications.

\section{5. ACE Inhibition Activity}

Angiotensin-I-converting enzyme (ACE) is a glycosylated zinc dipeptidyl-carboxypeptidase whose main function is to regulate arterial blood pressure by converting angiotensin I to angiotensin II, a potent vasoconstrictor. ${ }^{38}$ Thus, inhibition of ACE has been considered as important in the chronic treatment of various cardiovascular diseases. A series of synthetic ACE inhibitors, which have been clinically used as antihypertensive drugs, cause some adverse side effects in humans. ${ }^{39}$ Last years of the twentieth century were marked with increased worldwide interest in herbal medicine and the development of new drugs based on naturally occurring biologically active compounds. 
Within this context, in the present study the extracts obtained by maceration, UAE, and SWE extract obtained under optimal conditions (temperature of $200{ }^{\circ} \mathrm{C}$, extraction time of $25.6 \mathrm{~min}$ and $\mathrm{HCl}$ concentration of $0.0075 \%$ ) were assayed for their ACE inhibitory activity. The results of the ACE inhibition activity of $S$. officinale extracts are depicted in Figure 3 (Supplementary data, Table 1).

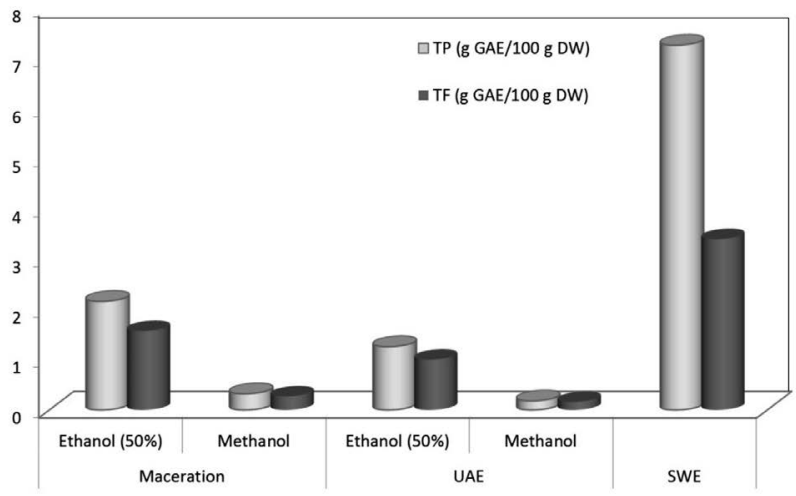

Figure 3. Antioxidant and ACE inhibition activity of comfrey root extracts obtained by different extraction techniques

All samples exhibited ACE inhibition. The subcritical water extract of comfrey root showed the highest ACE inhibitory with the $\mathrm{IC}_{50}$ being $0.18 \mu \mathrm{g} / \mathrm{mL}$. The lowest inhibitory activity was recorded for methanol extracts obtained by maceration $(5.24 \mu \mathrm{g} / \mathrm{mL})$. Ethanol fractions showed higher ACE inhibition activities than did methanol fractions. This is the first report with ACE inhibition evaluation from this plant. Previous studies on the ACE inhibition of some other plant extracts obtained by different extraction techniques indicated their strong activity. ${ }^{40,41}$ According to Wagner et al., ${ }^{42}$ the in vitro activity of some flavonoids was due to the formation of chelate complexes within the active centre of ACE. This chelate complex could be formed between a heterocyclic oxygen and a phenolic hydroxyl group in its vicinity. In studies reported by other authors, phenolic acids inhibited ACE via interaction with the zinc ion and this interaction was stabilized by other interactions with amino acids in the active site of ACE. ${ }^{31}$ Early works with S. officinale root extract indicated presence of some phenolic compounds such as rosmarinic acid, chlorogenic acid, caffeic acid, rutin, kaempferol, apigenin, quercetin. ${ }^{7,8}$ Some of these compounds such as caffeic acid, ${ }^{31} \mathrm{ru}-$ tin, ${ }^{43}$ quercetin, ${ }^{44}$ apigenin and kaempferol, ${ }^{45}$ were evaluated for their potency for ACE inhibition. The screening results of several plant methanolic extracts showed a low ACE inhibition activity of the isolated chlorogenic acid. ${ }^{32}$ Thus, based on the reported previous and present studies, it is feasible to suppose that the ACE inhibition activity of $S$. officinale root extracts may be due to its rich content of phenolic compounds. However, further research is needed to provide structural information of the ACE-inhibitory compounds from S. officinale root.

In addition, the present findings indicated the efficiency and potential use of subcritical water extracts for the development of antihypertensive functional foods and nutraceuticals formulation that would be economical and a natural alternative therapy to commercial synthetic drugs.

\section{6. Antiproliferative Activity}

Research for new anticancer drugs with improved pharmacological profiles is a very active domain. Natural products represent an important source of new drugs. A number of studies have demonstrated the anticancerogenic effects of bioactive compounds isolated from various plants.

In the current research, the influence of the extraction techniques on antiproliferative activity of comfrey root extracts was evaluated. MTT assay was used in the analysis of subcritical water extract obtained at optimal conditions and extracts obtained by maceration and UAE. Antiproliferative effects of extracts were determined for three human cancer cell lines: the human cervix carcinoma $(\mathrm{HeLa})$, breast cancer cell line (MDA-MB-453) and chronic myelogenous leukemia cell line (K562), as well as toward normal human lung fibroblast (MRC-5). Calculated activities of the tested extracts are summarized in $\mathrm{Ta}$ ble 7 .

Table 7. Antiproliferative activity of comfrey root extracts

\begin{tabular}{llcccc}
\hline Extraction & \multicolumn{4}{c}{ IC $_{\mathbf{5 0}}(\mathbf{m g} / \mathbf{m L})$} \\
& & HeLa & MDA-MB-453 & K562 & MRC-5 \\
\hline Maceration & Ethanol (50\%) & $>2$ & $>2$ & $>2$ & $>2$ \\
& Methanol & $>2$ & $>2$ & $>2$ & $>2$ \\
\multirow{2}{*}{ UAE } & Ethanol (50\%) & $0.719 \pm 0.028$ & $>2$ & $0.578 \pm 0.054$ & $>2$ \\
& Methanol & $>2$ & $>2$ & $>2$ & $>2$ \\
SWE & $0.337 \pm 0.005$ & $0.319 \pm 0.028$ & $0.209 \pm 0.027$ & $0.483 \pm 0.005$ & \\
\hline
\end{tabular}

Values are expressed as average \pm standard deviation 
Regarding antiproliferative effects, subcritical water extract of $S$. officinale root was the most toxic of all extracts screened (Table 7). The viability of cell lines was minimally affected by the extract obtained by maceration. The extract prepared by the SWE was the most active against $\mathrm{K} 562$ cell line $\left(\mathrm{IC}_{50}=0.209 \mathrm{mg} / \mathrm{mL}\right)$. Moderate $\mathrm{IC}_{50}$ values could be explained by the presence or synergistic activities of polyphenolic compounds in the extracts since the number of studies have suggested that anticarcinogenic activity is closely associated with this group of secondary metabolites. ${ }^{46}$, ${ }^{47}$ Qualitative phytochemical screening of S. officinale root have identified the presence of allantoin, rosmarinic acid, ellagic acid, caffeic acid, rutin, tannin, which are believed to contribute to the antiproliferative activity. ${ }^{7,8,36}$ Antiproliferative activity of plant extracts is also closely related to the extraction technique and the operational parameters applied during the process. Namely, subcritical water has much better selectivity in comparison to methanol and ethanol, being able to simultaneously extract different chemical classes. Therefore, by selecting the appropriate extraction parameters of subcritical water extraction, it is possible to influence the antiproliferative activity of extracts.

\section{Conclusions}

The results of the present study demonstrate that subcritical water extracts of $S$. officinale root are the promising sources of compounds with antioxidant, ACE inhibition and antiproliferative properties. Applied second-order polynomial model provided adequate mathematical description of SWE of investigated responses: TP, TF and antioxidant activity. Optimization of extraction conditions, in order to provide maximum yields for the observed responses, was successfully performed. Numerical optimization determined the optimum extraction conditions to be temperature of $200{ }^{\circ} \mathrm{C}$, extraction time of $26.5 \mathrm{~min}$ and $\mathrm{HCl}$ concentration of $0.0075 \%$. Predicted values of investigated responses on these conditions were $7.26 \mathrm{~g}$ GAE/ $100 \mathrm{~g} \mathrm{DW}, 3.40 \mathrm{~g} \mathrm{CE} / 100 \mathrm{~g}$ DW and 0.0058 $\mu \mathrm{g} / \mathrm{mL}$, for $\mathrm{TP}$, TF and $\mathrm{IC}_{50}$, respectively. Extraction temperature had notable influence on each investigated response, followed by effect of $\mathrm{HCl}$ concentration in extraction solvent. When compared to other extraction techniques, SWE indicated better bioactivity. According to the results, subcritical water extracts of $S$. officinale root can find application in the development and production of new safe, pharmacologically-active formulations. Taking into consideration the efficiency, functionality, and safety of the SWE process, present investigation also demonstrates the potency of subcritical water application in food and pharmaceutical technology.

\section{References}

1. F. Stickel, H. K. Seitz, Public Health Nutr. 2000, 3, 501-508.

2. M. Kucera, J. Kálal, Z. Polesna, Adv. Ther. 2000, 17, 204-211. DOI:10.1007/BF02850297

3. J. A. Duke, Chemicals and their biological activities, in: Symphytum officinale L. (Boraginaceae)-Comfrey, Phytochemical Database, USDA-ARS-NGRL, Beltsville Agricultural Research Center, Beltsville, MD, USA, 2002.

4. H. G. Predel, B. Giannetti, R. Koll, M. Bulitta, C. Staiger, Phytomed. 2005, 12, 707-714.

DOI:10.1016/j.phymed.2005.06.001

5. R. Andres, R. Brenneisen, J. T. Clerc, Planta Med. 1989, 55, 643-644. DOI:10.1055/s-2006-962224

6. B. Grabias, L. Swiatek, Pharm. Pharmacol. Lett. 1998, 8, 8184.

7. G. Paun, E. Neagu, S. C. Litescu, P. Rotinberg, G. L. Radu, J. Serb. Chem. Soc. 2012, 77.

8. V. L. Savić, S. R. Savić, V. D. Nikolić, L. B. Nikolić, S.J. Najman, J. S. Lazarević, A. S. Đorđević, Hem. Ind. 2015, 69, 1-8. DOI:10.2298/HEMIND131202013S

9. I. Ignat, I. Volf, V. I. Popa, Food Chem. 2011, 126, 1821-1835. DOI:10.1016/j.foodchem.2010.12.026

10. J. Wang, B. Sun, Y. Cao, Y. Tian, X. Li, Food Chem. 2008, 106, 804-810. DOI:10.1016/j.foodchem.2007.06.062

11. W. Setyaningsih, I. E. Saputro, C. A. Carrera, M. Palma, Food Chem. 2019, 288, 221-227.

DOI:10.1016/j.foodchem.2019.02.107

12. J. C. Martínez-Patiño, B. Gullón, I. Romero, E. Ruiz, M. Brnčić, J. S. Žlabur, E. Castro, Ultrason. Sonochem. 2019, 51, 487-495. DOI:10.1016/j.ultsonch.2018.05.031

13. G. Joana Gil-Chávez, J. A. Villa, J. Fernando Ayala-Zavala, J. Basilio Heredia, D. Sepulveda, E. M. Yahia, G. A. GonzálezAguilar, Compr Rev Food Sci Food Saf. 2013, 12, 5-23.

DOI:10.1111/1541-4337.12005

14. R. G. Maroun, H. N. Rajha, N. El Darra, S. El Kantar, S. Chacar, E. Debs, E. Vorobie, N. Louka, 2018. In Polyphenols: Properties, Recovery, and Applications (pp. 265-293).

15. H. F. Zhang, X. H. Yang, L. D. Zhao, Y. Wang, Innov. Food Sci. \& Emer. Technol. 2009, 10, 54-60.

DOI:10.1016/j.ifset.2008.09.007

16. J. Wang, Y. M. Zhao, Y. T. Tian, C. L. Yan, C. Y. Guo, Scientific World Journal, 2013.

17. J. Vladić, O. Canli, B. Pavlić, Z. Zeković, S. Vidović, M. Kaplan, J. Supercrit. Fluid. 2017, 120, 86-94.

18. M. Munir, H. Kheirkhah, S. Baroutian, S. Y. Quek, B. R. Young, J Clean Prod. 2018, 183, 487-494.

DOI:10.1016/j.jclepro.2018.02.166

19. S. Erşan, O. G. Üstündağ, R. Carle, R. M. Schweiggert, Food Chem, 2018, 253, 46-54.

DOI:10.1016/j.foodchem.2018.01.116

20. J. H. Lee, M. J. Ko, M. S. Chung, J. Supercrit. Fluid. 2018, 133, 177-183.

21. K. S. Duba, A. A. Casazza, H. B. Mohamed, P. Perego, L. Fiori, Food Bioprod. Process. 2015, 94, 29-38.

DOI:10.1016/j.fbp.2015.01.001 
22. M. Herrero, A. Cifuentes, E. Ibañez, Food Chem. 2006, 98, 136-148. DOI:10.1016/j.foodchem.2005.05.058

23. Z. Zeković, S. Vidović, J. Vladić, R. Radosavljević, A. Cvejin, M. A. Elgndi, B. Pavlić, J. Supercrit. Fluid. 2014, 95, 560-566.

24. M. P. Kähkönen, A. I. Hopia, H. J. Vuorela, J. P. Rauha, K. Pihlaja, T. S. Kujala M. Heinonen, J. Agric. Food Chem. 1999, 47, 3954-3962. DOI:10.1021/jf9901461

25. K. R. Markham, in: Harborne, J. B., Dey, P.M. (Eds.), Methods in Plant Biochemistry, Academic Press, London, 1989, pp. 193-237

26. J. C. Espín, C. Soler-Rivas, H. J. Wichers, J. Agric. Food Chem. 2000, 48, 648-656. DOI:10.1021/jf9908188

27. Y. Yoshie-Stark, Y. Wada, A. Wäsche, Food Chem. 2008, 107, 32-39. DOI:10.1016/j.foodchem.2007.07.061

28. T. Mosmann, J. Immunol. Methods. 1983, 65, 55-63. DOI:10.1016/0022-1759(83)90303-4

29. M. Ohno, T. Abe, J. Immunol. Methods. 1991, 145, 199-203. DOI:10.1016/0022-1759(91)90327-C

30. M. A. Bezerra, R. E. Santelli, E. P. Oliveira, L. S. Villar, L. A. Escaleira, Talanta. 2008, 76, 965-977.

DOI:10.1016/j.talanta.2008.05.019

31. A. Tomšik, B. Pavlić, J. Vladić, M. Cindrić, P. Jovanov, M. Sakač, A. Mandić, S. Vidović, J. Supercrit. Fluid. 2017, 128, 79-88.

32. R. K. Toor, G.P. Savage, Food Chem. 2006, 94, 90-97. DOI:10.1016/j.foodchem.2004.10.054

33. J. R. Vergara-Salinas, J. Pérez-Jiménez, J. L. Torres, E. Agosin, J. R. Pérez-Correa, J. Agric. Food Chem. 2012, 60, 1092010929.

34. L. He, X. Zhang, H. Xu, C. Xu, F. Yuan, Ž. Knez, Z. Novak, Y. Gao, Food Bioprod. Process. 2012, 90, 215-223.

DOI:10.1016/j.fbp.2011.03.003
35. A. Naffati, J. Vladić, B. Pavlić, R. Radosavljević, A. Gavarić, S. Vidović, J. Supercrit. Fluid. 2017, 121, 1-9.

36. F. U. Alkan, C. Anlas, O. Ustuner, T. Bakırel, A. B. Sari, Asian J. Plant Sci. Res. 2014, 4, 62-68.

37. M. Uematsu, E. U. Frank, J. Phys. Chem. Ref. Data. 1980, 9, 1291-1306. DOI:10.1063/1.555632

38. G. H. Li, G. W. Le, Y. H. Shi, S. Shrestha, Nutr. Res. 2004, 24, 469-486. DOI:10.1016/S0271-5317(04)00058-2

39. L. Paiva, E. Lima, A. I. Neto, J. Baptista, J. Funct. Foods. 2016, 26, 65-76. DOI:10.1016/j.jff.2016.07.006

40. N. Al Shukor, J. Van Camp, G.B. Gonzales, D. Staljanssens, K. Struijs, M. J. Zotti, K. Raes, G. Smagghe, J. Agric. Food Chem. 2013, 61, 11832-11839. DOI:10.1021/jf404641v

41. M. A. Lacaille-Dubois, U. Franck, H. Wagner, Phytomed. 2001, 8, 47-52. DOI:10.1078/0944-7113-00003

42. H. Wagner, G. Elbl, H. Lotter, M. Guinea, Pharm. Pharmacol. Lett. 1991, 1, 15-18.

43. H. M. Shaw, J. L. Wu, M. S. Wang, J. Funct. Foods. 2017, 35, 68-73. DOI:10.1016/j.jff.2017.05.033

44. H. Wagner, ACS Symposium Series. 1998, 691, 46-61.

45. L. Guerrero, J. Castillo, M. Quiñones, S. Garcia-Vallvé, L. Arola, G. Pujadas, B. Muguerza, PLOS one. 2012, 7, e49493. DOI:10.1371/journal.pone.0049493

46. S. Vuorela, K. Kreander, M. Karonen, R. Nieminen, M. Hämäläinen, A. Galkin, L. Laitinen, J.P. Salminen, E. Moilanen, K. Pihlaja, H. Vuorela, J. Agric. Food Chem. 2005, 53, 5922-5931. DOI:10.1021/jf050554r

47. K. A. Lee, K. T. Kim, P. S. Chang, H. D. Paik. J. Ginseng Res. 2014, 38, 289-292. DOI:10.1016/j.jgr.2014.05.009

\section{Povzetek}

Študija preučuje možnost uporabe vode v subkritičnih pogojih za ekstrakcijo bioaktivnih substanc iz korenine Symphytum officinale (navadni gabez). Preverili smo vpliv temperature $\left(120-200^{\circ} \mathrm{C}\right)$, časa ekstrakcije (10-30 min) in koncentracije $\mathrm{HCl} v$ ekstrakcijskem topilu (0-1.5 \%), da bi določili optimalne pogoje ekstrakcije ter maksimirali izkoristek skupnih fenolov, flavonoidov ter antioksidativne aktivnosti ekstrakta. Z uporabo optimalnih pogojev $\left(200{ }^{\circ} \mathrm{C}, 25.6 \mathrm{~min}\right.$ in $0.0075 \%$ ) smo dobili ekstrakt bogat s skupnimi fenoli in flavonoidi ter visoko antioksidativno aktivnostjo. Rezultati kažejo izrazite prednosti uporabe subkritične vode za pridobivanje biokativnih substance iz korenin gabeza v primerjavi $\mathrm{z}$ maceracijo in ultrazvočno ekstrakcijo. Poleg tega pa ekstrakti korenine S. officinale pridobljeni z ekstrakcijo z vodo v subkritičnih pogojih predstavljajo obetaven vir snovi z antioksidativnimi, ACE inhibitornimi in antiproliferativnimi lastnostmi in bi lahko predstavljale potencialen vir za proizvodnjo novih farmakološko aktivnih formulacij. 